\title{
Seeking Growth in Solitude Journey - On Thomas Wolfe Angel, Look Homeward
}

\author{
Guiying Zang, Hong Yang, Junyan Cai \\ School of foreign languages, Hebei University of Technology, Tianjin 300130
}

Keywords: Angel, Look Homeward, Growth novel, Narrative mode, Mentality

\begin{abstract}
Thomas Wolfe's "Angel, Look Homeward", describes the absence of Eugene in the family lives lost - escape - search - Return to childhood. In this paper, the theory of the growth of the novel, the protagonist in solitude in the quest to explore the growth journey of understanding the mentality of the development process of the world from the narrative mode and the hero, so that readers a deeper understanding of this autobiographical Bildungsroman.
\end{abstract}

\section{Text}

Thomas Clayton Wolfe (Thomas. Clayton. Wolfe) (1900--1938) is a contemporary American novelist. He made his short life to create four novels - "Angel, Look Homeward", (Look Homeward, Angel), "Time and the river", (of Time and the River), "cobweb and rock", (The Web and the Rock), "you can not go home again", (You Can not Go Home Again). Wherein, after the two novels are edited in order on the basis of their manuscripts published. In addition, in its lifetime also published short stories "from the dead in the morning" (From Death to Morning), and an unfinished novel, "mountains", (The Hills Beyond). Four novels are autobiographical novel Wolf on the basis of their own experience and the experience of the written, it reflects a common confusion Bildungsroman quest - Return theme. Among them, the "Angel, Look Homeward" highest literary achievement. Just a novel published on the subject of the Nobel Prize winner Sinclair Lewis and William .Faulkner highly commended. "Beat Generation" will be more representative of Kerouac. Thomas. Wolfe literary idol seen on the road. Wolf himself has deservedly become the "Lost Generation" outstanding representatives.

Currently, for the "Angel, Look Homeward," the study abroad, mainly from the writer's upbringing, social background, work relating to intellectual and artistic style, and a detailed study. Domestic research on this work focused on the works explore themes and ideas from existential philosophy or transcendental theory point of view, or the image of the characters in the novel, started to explore the artistic style or imagery.

"Angel, Look Homeward" third person standing in the narrative perspective, about the hero Eugene Lost - search - Return of action and psychological history, portraying the psychological conflict of the protagonist in the process of conflict, struggle on the heart and, ultimately, wandering, lonely hearts find a spiritual home. Whether from fiction narrative mode, or understanding of the development process to see the world from the hero, we are in line with the growth characteristics of the novel. Bildungsroman usually translated as "initiation novel". In the Bildungsroman, the hero is usually felt in the real world, lost, lonely, find direction, so through various means to pursue, after a series of temper, and finally re-understanding of self, in the real world to get a peace of mind .

Fiction outset hint of loneliness, loss, and then search for the topic. "...... A stone, a leaf, a door has not been found," and "who is not to be imprisoned for life? Who is not alone as a stranger through life?", "We look for that great the forgotten language, look for the missing piece of the path to heaven. "hero Eugene was born in 1900. The author was a lot of historical events described. But this is not the slightest effect on the selfish pleasure of Gantt and bent enrichment according to Lisa. Eugene before birth, drink drunk Gantt are spent sleeping, while his wife endured severe prenatal pains. Eugene after birth, Gantt quickly whining himself this age, but also to suffer to keep a mouth. Think this is horrible, it's horrible, really cruel. From birth, Eugene was seen as the father is a burden, and brothers and sisters of the language and actions often do not promote their understanding of Eugene, but increased 
conflict and pain. Lack of family care and communication, Eugene's life must be lonely path along the front line. 1904, are determined to own property except with Eliza Daisy kids outside to St. Louis to look for opportunities. Here, Eugene's first face death - the death of Grove. Grove and others distinct temperament, is the most gentle boy, one of the most sad, yet typhoid fever left. Faced with Grove's body through that little body, Eugene felt "strange, bright lonely." Hearts, "lost ah, the wind weeping, ghost, return it," he cries never stopped since then. 。 Grew up in Eugene, began looking for the key to open the wisdom from reading picture books and reciting Shakespeare, who plays in. During this time the young Eugene are happy, forget their loneliness, despite his family's friends are few, because their home to a normal life completely distorted. Their lives are filled with abuse, violent. Less than six years old Eugene finally won the chance to leave home for the first time - to school. Eugene greedily learn the knowledge, in this vast world wander, my brother and sister who are busy with their own problems to attend to him. However, this freedom, this isolation in the text of life did not last long, because according to Lisa Gantt and support economic independence, all the boys at a very young age to be sent out to make money. Eugene began the day selling newspapers, although he hated the job. That was not enough, Gantt doing their utmost way to stimulate their little son - "! Ungrateful Yeah, than the most vicious beast not as" and after seeing face twitching, remorse look for fun. These actions long road marked with a deep imprint of pain.

Eliza quite business-minded bought "Dixieland", an inn, and then took less than eight, Eugene moved to the inn. This is a decisive turning point for the development of the family, living together between Eliza and Gantt disintegration, the bustle of family life vanished. Eugene feel "Dixieland" is a cold grave, which occasionally are attracted Gantt home charm, but then Lisa would be in accordance with sarcasm, "You go where your dad is mean anything ? if I were you, it was not so cheap. shame. "in the" Dixieland ", Eugene spirit languish in frustration, despair and frustration. With more houses to live more full, space belonging to Eugene less and less. Since the move away from the original home, Eugene friendships with neighborhood children almost completely cut off. His playmates only those tenants child, and Eugene felt their hearts and happiness are boring and tedious, so feel very tired. Then Eugene fast twelve years old.

Because literature outstanding performance, Eugene was sent to private school, "Altamonte preparatory school in four years here, Eugene encountered a spiritual mentor. - Margaret Margaret appear very Eugene extent make up for the lack of maternal love and affection. more importantly, she continues to guide the spiritual Eugene. "It was her light illuminated his dark eyes, it was she for him homeless providing a home loss of the soul. "Margaret asked him not to take health joke, life should be the law. This is obsessed with the accumulation of assets, no time to be concerned about their children's Eliza in stark contrast. When Eugene to go to college, Margaret special soulful told Eugene, "Even if you are our own children, our love for you will not be more than it is now."At the high school during World War I broke out, Eugene imagined I could go join the army, but it is not enough because of their age, could not go into. But it also led to his inquiry," we come from? Where? Why are we alive? "

Four years later, when Eugene high school graduation, fast sixteen years old, he has crossed the youth, he tends to become mature. In the Gantt's insistence, went to the State University Eugene, when he still was a child, a "Looking at the suffering and evil," but still believe the beauty and order, and believe in love, I believe the heroic ideal of infatuation visionaries. "But in the first year of university life for Eugene is a failure, he left alone, no friends, become the object of ridicule classmates, for full Xiufen, heart his heart, but no place to talk, loneliness, pain tightly around him. Eugene heart lost so distraught, we are in a rebellious phase of his life is full of hostility. Just then, the "Dixieland", Eugene met labor pull. Laura is a big year-old than Eugene, looks ordinary girl. two lonely hearts in love to Eugene brought hope, because he knows he will have little to rely on people alive, he could not be like his parents as live without light, no love, no comfort day. However, Laura has been engaged in fact, soon after leaving Eugene and her fiance were married. The failure of love experience, so Eugene for yourself a deeper understanding of the Eugene maturity rite, is to explore the crucial step on the road. Romance so very painful Eugene, who tried to talk like Margaret, but Margaret felt his age is still small, his words without let-care. Finally, Eugene irrepressible yearning 
for Laura, north Virginia. There, Eugene spent all their savings, had looked for work. During this time, there is no warmth to escape home, Eugene wandering. This is a soul, trying to groping to find freedom, to find the lost door door. While exploration is blind, but it is the beginning of a journey of life. Lonely days, Eugene began to reflect on the living conditions of their families: Gantt, who lived in the old days in the "Titan"; Eliza, preoccupied with the accumulation of wealth; this, like a stranger in on the road of life and life's groping, but still could not find the door. These are Eugene sounded the alarm. Homeless, hungry days to make Eugene almost starved, but it is the plight of hunger and survival, so that he almost seen death, he began to understand the pain and love.

The departure of so Eugene real insight and understanding death. This is the home of the most understanding of the relationship between Eugene and his people. However, once he pneumonia at his life. From itself, Eugene saw this lifelong search has not found the door of the tragedy of life. And this is hard to find and I do not know the direction of Eugene microcosm, which further strengthened Eugene to flee in search of determination. Pursuit of the road, Eugene seems to be blind and not know the direction, but this is precisely the relentless quest for power.

After graduating from Harvard University in Eugene ready to go for further study. Eliza Gantt despite opposition, the Gantt Woodson Street in the old house sold, which marks the disintegration of the family, past the hustle and bustle of the old life never ceased to exist. Harvard embark on the road, is the beginning of the journey of Eugene, and to aiming for, he is still not very clear. At the end of the novel, with the specter of the Eugene we conducted a meaningful dialogue. Ben told Kim, "You are your world." Ben tells him that life is a journey, life is the constant pursuit. And Eugene has also been encouraged, he vowed to have to find that forgotten language, that lost world, one can enter the door. At this point, he has not only limited vision home town, but "turned to the distant towering mountains."

End of the novel the hero does not seem to indicate a clear direction, but this is life, life is not a pre-designed, as a person walking on the road, we need to be high-spirited attitude, to meet life given to us all . Under this guidance, Eugene finally realized out of the inner confusion, loneliness is not on the surface, but in the heart, in the heart of the city, in the soul of the continent.

Throughout the entire novel, the protagonist has experienced growing process as follows: the lack of affection and family relations as well as exchange of sensitive genetic temperament from his father to the artists who made him feel lonely, find yourself; to get rid of the spiritual dilemma hero constantly study, from knowledge to learn wisdom, and continue to flee, with action to experience. In thinking and action, the hero recognized the "self" is to save their roots, although the road ahead is still not very clear, but the hero has to get rid of the lost emotions, positive and optimistic attitude will embark on a new journey.

\section{References}

[1] Thomas Wolf Angels, Look Homeward - life story was buried. Beijing: People's Literature Publishing House, 2011

[2] Lin Yan. "Angel, Look Homeward" in the imagery presented. Foreign Literature, 2008.

[3] Lin Xiali "Angel, Look Homeward" in the image "door" to analyze the character of spiritual growth. Fuzhou: Fujian Normal University, 2011.

[4] Meng Yi resolution "Angel, Look Homeward" to guide the hero of the characters growing up. Jilin: Jilin University, 2009.

[5] Rui Yu Ping of American Bildungsroman. Beijing: China Social Sciences Publishing House, 2004.

[6] Lin Yan study from Goethe to Saul Bellow Bildungsroman. Changchun: Jilin University College, 2008. 
[7] Jiangai Qin loneliness and contradictions in the growth - On Thomas Wolfe's "Angel, Look Homeward" . Jilin: Northeast Normal University, 2011

[8] Lin Yan approached "Bildungsroman" - the concept of "Bildungsroman" early on. PLA University of Foreign Languages, 2007...

[9] Rui Yu Ping American Bildungsroman literature. Sichuan International Studies University, 2000. 